ljtihad: Jurnal Wacana Hukum Islam dan Kemanusiaan

Vol. 19, No. 1 (2019), pp. 67-87, doi : 10.18326/ijtihad.v19i1.67-87

\title{
Revitalisasi hukum waris Islam dalam penyelesaian kasus sengketa tanah waris pada masyarakat Sasak
}

\author{
Lalu Supriadi Bin Mujib \\ Universitas Islam Negeri (UIN) Mataram \\ E-mail: nasabila46@gmail.com \\ DOI: 10.18326/ijtihad.v19i1.67-87
}

The inheritance issue is considered crucial to evaluate since it is closely related to inheritance transfer from the deceased to the living family and death is natural and common phenomenon. This research aims to investigate the inheritance legal system, the factors influencing the land dispute cases and the revitalization of Islamic legal system to reach a settlement of this land dispute issues. This field research employs qualitative approach using field and library research with socio-legal approach. The research data is categorized into two, primary and secondary data. The data was obtained using observation technique, interview, and doccumentation. The results indicate that: First, the distribution of inheritance land is conducted in different ways such as grants, discussion, and faraid. Second, the factors influencing the land dispute cases are greed and lack of information about inheritance legal system, so the society do not know the legal system related to the inheritance. Third, revitalization is important because it is ruled out in Islamic teachings and is considered absolute for Islam society. This research conludes that Islamic Inheritance legal system is the best alternative to reach a settlement of land disputes in Sasak community.

Masalah waris menjadi penting untuk dikaji karena berkaitan dengan pemindahan harta waris dari orang yang meninggal dunia (pewaris) kepada keluarga yang masih hidup (ahli waris) atas dasar bahwa semua orang pasti mengalami peristiwa kematian. Penelitian ini bertujuan untuk mengetahui praktek hukum waris, faktor penyebab munculnya kasus sengketa tanah waris dan revitalisasi hukum waris Islam dalam penyelesaian kasus sengketa tanah waris. Penelitian lapangan ini menggunakan pendekatan kualitatif dengan desain field research dan library research serta menggunakan penelitian sosiologi hukum. Data penelitian dikategorikan menjadi dua, yaitu data primer dan data sekunder. Sumber data diperoleh dengan menggunakan tekhnik observasi, wawancara dan dokumentasi. Berdasarkan hasil penelitian ditemukan bahwa: Pertama, praktek pembagian tanah 
waris mengikuti berbagai cara, antara lain pertama, hibah, musyawarah dan faraid. Kedua, faktor penyebab munculnya kasus sengketa tanah waris adalah keserakahan dan ketamakan, kurangnya sosialisasi mengenai hukum waris Islam, ketidaktahuan masyarakat mengenai hukum waris Islam. Ketiga, revitalisasi menjadi penting dilakukan karena sebagai bentuk pelaksanaan perintah agama dan merupakan ketaaan kepada Allah dan dianggap sebagai hukum yang berlaku secara mutlak. Penelitian ini menyimpulkan bahwa hukum waris Islam menjadi solusi bagi kasus sengketa tanah waris yang terjadi pada masyarakat Sasak.

Keywords: legal system, plural, system, land disputes, alternative

\section{Pendahuluan}

Realita hukum waris yang berkembang pada masyarakat Indonesia bersifat plural (majemuk), artinya terdapat beragam sistem hukum yang berada dalam suatu kehidupan sosial (Nasution, 2018:20). Pluralistiknya sistem hukum waris di Indonesia tidak hanya disebabkan oleh pengaruh sistem hukum yang pernah hidup dan berkembang sejak era pra penjajahan Belanda sampai saat sekarang ini, namun juga sistem kekeluargaan yang beragam dan adat istiadat masyarakat yang juga dikenal sangat bervariasi. Terdapat tiga sistem hukum waris yang berkembang dan berlaku di Indonesia: hukum waris Islam, hukum waris Adat dan hukum waris Barat (Abbas, 2012:231). Masing-masing dari sistem hukum ini dibangun berdasarkan kerangka dan realitas hukum yang berbeda antara satu dengan yang lainnya (Abbas, 2012:232-235). Hukum waris Islam dibangun di atas landasan ajaran Islam, dan secara normatif bersumber dari ayat-ayat al-Qur'an dan hadits Nabi Muhammad SAW. Sekalipun demikian, kondisi sosiokultural masyarakat Arab kala turunnya wahyu turut serta mempengaruhi konstruksi hukum waris Islam.

Konstruksi hukum waris Barat tentu berbeda dengan hukum waris Islam. Hukum Waris Barat merupakan peninggalan zaman Hindia Belanda yang bersumber pada BW (Burgerlijk Wetboek) yang termuat dalam Kitab Undang-Undang Hukum Perdata (KUHP). Ia berdiri di atas bangunan paham Barat yang menganut paham individualisme, yaitu seseorang secara individu memiliki kebebasan dan kemerdekaan secara mutlak untuk memiliki dan membelanjakan harta yang diperolehnya baik melalui warisan maupun yang lain tanpa terikat oleh tuntutan sosial. Dalam masyarakat Adat, filsafat yang melandasi bangunan hukum waris adat adalah nilai-nilai tanggung jawab bersama dan komunalitas yang kemudian 
menjadi nilai essensial dalam kehidupan. Peran tokoh adat dan nilai-nilai luhur dan kearifan lokal (local wisdom) yang dianut menjadi pertimbangan penting dalam hukum waris Adat.

Memetakan sistem waris yang berlaku pada masyarakat Sasak (suku asli yang mendiami pulau Lombok) menjadi menarik, karena ciri khas budaya dan adat istiadat yang berlaku turun temurun dan terbentuk melalui proses dan dinamika sejarah yang panjang. Secara historis di samping pengaruh kolonial Belanda, ada tiga kebudayaan yang berpengaruh besar dalam membentuk watak dan karakter adat istiadat masyarakat Sasak. Pertama, pengaruh kebudayaan Jawa dalam bidang kebudayaan dan agama dari abad ke-15 sampai ke-16 M. Kedua, gabungan pengaruh politik Bali dan Makasar pada abad ke-17 M. Ketiga, konsolidasi kekuasaan politik Bali dari permulaan abad ke-18 M sampai seterusnya (Van der Kraan, 2009:3).

Ketidakseragaman sistem hukum waris yang berkembang dan dipraktekkan oleh masyarakat Sasak tidak hanya meninggalkan dampak positif seperti menunjukkan kekayaan khazanah intelektual dan warisan adat dan budaya. Namun memunculkan dampak negatif dengan munculnya beberapa konflik kasus sengketa tanah waris yang ditandai banyaknya pengaduan kasus sengketa tanah waris yang ditangani Pengadilan Agama Selong Lombok Timur. Berdasarkan data yang diperoleh, pada tahun 2014 Pengadilan Agama Selong menempati urutan pertama kasus sengketa tanah waris terbanyak untuk wilayah NTB dan Bali (www.badilag.net/seputar-peradilan- agama).

Berangkat dari permasalahan ini maka revitalisasi hukum waris Islam merupakan tawaran solusi terkait dengan sengketa tanah waris dengan asumsi pokok bahwa ajaran Islam muncul karena hukum Islam sangat berpengaruh dan efektif dalam membentuk tatanan sosial dan kehidupan umat Islam. Di pihak lain, hukum sangat penting guna memahami karakter bangsa dan menggambarkan jiwa masyarakat (Mu'alim, 2001:20). Kaitannya dengan teori klasik Islam, hukum bersumber kepada kehendak Ilahi, sehingga dinyatakan bahwa pemberi hukum dalam Islam adalah Allah.

Kajian tentang hukum waris di Indonesia sudah banyak dilakukan oleh para akademisi. Di antara para akademisi, ada yang fokus mengkaji pelaksanaan hukum waris di beberapa daerah antara lain Sulawesi, Lombok dan Semarang. Wahidin dkk. menyimpulkan bahwa kontekstualisasi pelaksanaan hukum waris dalam masyarakat Bugis terjadi karena adanya 
Ijtihad: Jurnal Wacana Hukum Islam dan Kemanusiaan, Volume 19, No. 1, Juni 2019: 67-87

proses asimilasi dalam penerapan hukum Islam dan hukum Adat. (Fikri \& Wahidin 2017:193). Erman Rajagukguk mengklasifikasikan sistem waris yang diterapkan pada masyarakat Sasak menjadi tiga macam yaitu, hukum waris Adat, hukum waris Islam dan hukum waris Perdata (Rajagukguk, t.t: 1). Wahyu Setiadi menyimpulkan pembagian harta warisan di desa Sugihan Kecamatan Tengaran Kabupaten Semarang menggunakan hukum waris Adat dalam bentuk lintiran (hibah) yaitu setelah pewaris meninggal dunia dengan alasan bahwa pelaksanaan hukum waris Adat sudah dilakukan secara turun-temurun dan diyakini lebih mencerminkan rasa keadilan (Setiadi and Sumarto, 2014:18).

Para akademisi ada yang melakukan perbandingan antara hukum waris Islam dengan hukum waris Adat seperti Rahmat Haniru (Haniru and Thamrin, 2014:456), sementara yang lain menyoroti tentang faktor-faktor yang menghalangi penerapan sistem hukum waris Islam di Indonesia, seperti Sakirman yang menyimpulkan bahwa hukum waris Islam belum dapat terlaksana di Indonesia karena masyarakat masih dipengaruh oleh hukum waris Adat dan umat Islam belum sepenuhnya memahami konsep keadilan dan kesetaraan dalam hukum waris Islam (Sakirman, 2016.:155). Berbeda dengan Rosidi Jamil yang mengetengahkan pemikiran Hazairin dan Munawwir Sjadzali yang menekankan perlunya me-reaktualisasi ajaran Islam termasuk pembagian harta waris (Jamil 2017:99). Senada dengan itu Muhammad Muhibbuddin menyimpulkan bahwa telah terjadi pembaruan hukum waris Islam yang dilakukan oleh hakim di lingkungan Mahkamah Agung dalam bentuk pemberian bagian harta dari pewaris muslim bagi ahli waris non muslim melalui konsep wasiat wajibah (Muhibbuddin 2015:187).

Eka Susylawati dalam penelitiannya mengenai pluralisme hukum waris di Indonesia menyimpulkan bahwa dengan terbitnya Undang-Undang Nomor 3 Tahun 2006 tentang Perubahan Undang-Undang Peradilan Agama, pilihan hukum bagi orang yang beragama Islam secara otomatis akan menjadi kewenangan Pengadilan Agama dan akan menerapkan hukum waris Islam (Susylawati 2015:315). Afidah Wahyuni dalam penelitiannya mengenai urgensi sistem waris Islam menegaskan pentingnya mempelajari hukum waris Islam agar seseorang terhindar dari dosa memakan harta orang yang bukan haknya, karena tidak ditunaikannya hukum Islam mengenai kewarisan (Wahyuni 2018:147). Beberapa pandangan para akademisi di atas nampak belum ada yang menyentuh tentag revitalisasi hukum waris 
Islam dalam penyelesaian kasus sengketa tanah waris pada Masyarakat Sasak. Oleh karena itu, penelitian ini berusaha menganalisis sistem waris masyarakat Sasak. Tujuan penelitian ini adalah untuk mengetahui praktek hukum waris, faktor penyebab munculnya kasus sengketa tanah waris dan revitalisasi hukum waris Islam dalam penyelesaian kasus sengketa tanah waris.

Penelitian ini menggunakan pendekatan kualitatif dengan desain field research dan library research (Nawawi 1993:72). Selain kualitatif, peneliti juga menggunakan penelitian sosiologi hukum yaitu analisa data didekati dari suatu gejala dari aspek sosial, interaksi dan jaringan hubungan sosial yang semuanya mencakup dimensi sosial kelakuan manusia (Arikunto 1992:236). Pengumpulan data menggunakan tekhnik observasi, wawancara dan dokumentasi). Data penelitian dikategorikan menjadi dua, yaitu data primer dan data sekunder. Tekhnik analisa data yang dipergunakan adalah reduksi data, display (penyajian) data dan pengambilan kesimpulan dan verifikasi. Setting penelitian dilaksanakan di beberapa desa di kabupaten Lombok Timur antara lain Desa Kotaraja, Desa Loyok, Desa Tetebatu, Desa Kembang Kuning dengan pertimbangan bahwa daerah-daerah tersebut adalah tempat signifikan terjadinya sengketa tanah waris.

\section{Hukum waris Islam dalam literatur}

Secara etimologi kata waris berasal dari kata Irts yang merupakan bentuk mashdar dari kata waritsa - yaritsu - irtsan. Makna dasarnya adalah perpindahan harta milik atau perpindahan harta pusaka (Parman, 1995:23). Dalam literatur Islam, hukum waris Islam sering disebut dengan fiqih mawarits. Fiqib artinya memahami dengan baik (Mushthafa, 1410:698). Menurut istilah memahami hukum-hukum syara' yang bersifat praktek (perilaku) yang diambil dari dalil-dalil yang terperinci (al-Jurjani, 1417:216). Dengan demikian maka dalam konteks ini fiqih diartikan secara bahasa karena ia disandarkan kepada kata mawarits. Berkaitan dengan kata mawarits, dalam literatur fiqih Islam terdapat beberapa istilah yang dipergunakan untuk menyebutnya, antara lain faraidh, tarikah, mawarits. Kata faraidh merupakan bentuk jamak dari lafaz faridhah yang mengandung arti mafrudhah yang sama artinya dengan muqaddharah yaitu sesuatu yang ditetapkan bagiannya secara jelas dalam Qur'an dan Hadits. Dengan demikian istilah faraidh didasarkan pada bagian yang diterima oleh ahli waris (Sabiq, 1422:302). 
Ijtihad: Jurnal Wacana Hukum Islam dan Kemanusiaan, Volume 19, No. 1, Juni 2019: 67-87

Sementara kata tarikah adalah lebih melihat kepada obyek hukum yaitu harta benda yang ditinggalkan oleh orang yang meninggal dunia kepada ahli waris dan berlaku secara umum baik dalam bentuk harta benda atau hak-hak lain yang berkaitan dengan harta benda (Sabiq, 1422:302). Sedangkan penggunaan kata mawarits melihat kepada yang menjadi obyek dari hukum ini yaitu harta yang beralih kepada ahli waris yang masih hidup dan kata mawarits merupakan bentuk jamak dari mirats yang berarti mauruts yaitu harta yang diwarisi. Dengan demikian maka arti kata warits yang dipergunakan merujuk kepada orang yang menerima harta warisan itu karena kata warits artinya adalah pewarits (orang yang menerima warisan) (Fauzan, 1419: 13). Jadi fiqih mawarits adalah pengetahuan tentang seperangkat peraturan tertulis berdasarkan wahyu Allah dan Sunnah Nabi tentang hal ihwal peralihan harta atau berwujud harta dari yang telah mati kepada yang masih hidup yang diakui dan diyakini berlaku dan mengikat untuk semua yang beragama Islam (Syarifuddin, 2005:6).

Hukum waris Islam bisa terlaksana dengan terpenuhinya tiga rukun sebagai berikut: Pertama. al-muwarrith (pewaris), yaitu orang yang mewariskan dan yang meninggal dunia, baik meninggal dunia secara hakiki atau sebab putusan hakim. Kedua, al-mauruth (harta warisan), harta peninggalan si mati yang akan dipusakai setelah dikurangi biaya perawatan hutang, zakat dan setelah digunakan untuk melaksanakan wasiat. Harta pusaka disebut juga mirath, irth, dan tirkah. Harta atau hak yang dialihkan kepada ahli waris dari orang yang mewariskan. Ketiga, al-warits (ahli waris) yaitu orang yang akan diwarisi yang mempunyai hubungan dengan al-muwarrith baik hubungan itu sebab kekeluargaan (nasab) maupun perkawinan (Darmawan, 2014:7).

Menurut konsep Islam aturan dan kaidah mengenai siapa yang berhak menerima, ukuran harta yang diterima dan segala syarat dan konsekuensi hukum terkait masalah ini diatur secara jelas dan gamblang di dalam teks-teks al-Qur'an dan hadits yang kemudian dikenal dengan nama hukum waris Islam (Ilyas, 2015:125). Dalam perkembangannya hukum waris mengalami dinamika yang terkait dengan situasi dan kondisi sosiokultural masyarakat yang melatari berdirinya bangsa Indonesia. Keragaman budaya, agama, bahasa, dan adat istiadat serta dinamika politik pada masa pra penjajahan khususnya dan pasca kemerdekan pada umumnya turut serta mewarnai arah baru perkembangan hukum waris. Faktor-faktor ini berpengaruh kuat terhadap munculnya teorisasi dan polarisasi hukum waris di Indonesia secara umum dan masyarakat Sasak secara khusus. 
Revitalisasi hukum waris Islam dalam penyelesaian kasus sengketa tanah ...(Lalu Supriadi Bin Mujib)

Hukum Islam mengatur seluruh aspek kehidupan manusia baik untuk mewujudkan kebahagiaan di atas dunia ini maupun untuk mencari kebahagiaan di akhirat kelak. Ia dibangun di atas prinsip jalbul mashlahah (mengambil kebaikan) dan dar'ul mafsadah (menolak kerusakan). Aspek kehidupan manusia yang diatur tersebut mencakup dua aspek; Pertama, aspek yang berkaitan dengan hubungan manusia dengan Allah yang disebut hukum ibadah yang bertujuan menjaga hubungan antara hamba dengan Allah Pencipta-Nya (bablun min Allab). Kedua, aspek yang berkaitan dengan hubungan antar manusia dengan manusia dan alam sekitar yang disebut dengan mu'amalah yang bertujuan menjaga hubungan antara manusia dengan alam sekitar (hablu min al-nas) (Qs. Al-Imran: 112).

Di antara aturan yang mengatur hubungan antar sesama adalah aturan tentang warisan yaitu harta benda yang muncul akibat kematian seseorang berkaitan tentang siapa yang berhak menerimanya, bagaimana jumlahnya dan bagaimana cara mendapatkannya. Aturan tersebut ditegaskan Allah dalam al-Qur'an dan dijelaskan, atau ditegaskan atau dirinci oleh Rasulullah Saw dalam haditsnya dan selanjutnya dirumuskan dalam bentuk ajaran yang bersifat normatif oleh para pakar hukum Islam.

Bagi umat Islam Indonesia aturan tentang kewarisan menjadi hukum positif yang dipergunakan dalam Pengadilan Agama dalam memutuskan kasus pembagian maupun persengketaan berkenaan dengan harta waris. Dengan demikian maka umat Islam yang telah melaksanakan hukum Allah dalam penyelesaian harta warisan di samping telah melaksanakan ibadah dengan melaksanakan aturan Allah dalam waktu yang sama telah patuh kepada aturan yang telah ditetapkan negara.

\section{Relasi antara hukum waris Islam dan hukum waris adat}

Dalam mengkaji pelaksanaan hukum Islam termasuk di dalamnya hukum waris Islam terjadi perdebatan sengit antara para pakar dan ahli hukum mengenai status hubungan antara hukum Islam dan hukum adat. Muncul tiga teori mengeni hubungan antara keduanya; Pertama, teori receptio in complexu. Teori ini dipelopori oleh L.W.C. Van der Berg (1845-1927) yang mengemukakan bahwa orang Islam di Indonesia telah melakukan resepsi (menerima) hukum Islam secara keseluruhannya sebagai satu kesatuan yang tak terpisahkan (Ali, 1991:16). Kedua, teori receptie. Teori ini dipelopori oleh Cristian Snouck Hurgronje 
Ijtihad: Jurnal Wacana Hukum Islam dan Kemanusiaan, Volume 19, No. 1, Juni 2019: 67-87

(1857-1936) dan dikembangkan oleh C. van Vollenhoven dan B. ter Haar Bzn yang mengemukakan bahwa hukum Islam menjadi hukum kalau sudah diterima oleh hukum Adat (Ali, 1991:17). Ketiga, teori receptio a contrario. Teori ini dipelopori oleh Hazairin (19051975) yang mengatakan bahwa hukum adat dapat menjadi hukum yang berlaku dalam masyarakat muslim jika tidak bertentangan dengan hukum Islam (Ali, 1991:17). Tiga teori tersebut menjadi penting setidaknya untuk memetakan realitas masyarakat Sasak terkait sitem pembagian harta waris.

Realitas masyarakat menunjukkan bahwa konsep-konsep Islam dalam pembagian harta waris pada masyarakat Sasak sudah dikenal secara luas dan itu muncul dalam ungkapanungkapan berikut: "adat besendi syara" (hukum adat mengacu kepada hukum syara'/ Islam) dan "si nine bereson" (wanita menjunjung satu bakul di kepalanya), si meme belembah" (laki-laki membawa pikulan di bahunya) dan pikulan ini selalu terdiri dari dua bakul atau keranjang. Maksud dari ungkapan ini adalah anak perempuan dari pewaris mendapatkan satu bagian dari harta warisan, sementara anak laki mendapatkan dua bagian. Konsep Islam dalam pembagian warisan saat ini, tertuang dalam Kompilasi Hukum Islam (KHI) yang merupakan sekumpulan materi hukum Islam yang ditulis dalam pasal demi pasal. Pasal-pasal yang termuat dalam KHI berjumlah 229 pasal; terdiri dari tiga materi hukum yaitu hukum perkawinan 170 pasal, hukum kewarisan termasuk wasiat dan hibah 44 pasal dan hukum perwaqafan 14 pasal ditambah satu pasal ketentuan penutup. Berdasarkan ketentuan KHI Buku II tentang hukum kewarisan pasal 171 butir a) yang dimaksud dengan hukum kewarisan adalah hukum yang mengatur tentang pemindahan hak pemilikan harta peninggalan (tirkah) pewaris, menentukan siapa-siapa yang berhak menjadi ahli waris dan berapa bagiannya masing-masing.

Berbeda dengan hukum waris Barat yang termuat dalam Kitab Undang-Undang Hukum (KUH) Perdata. Dalam KUH Perdata hukum waris diatur pada buku II, jumlah Pasal yang mengatur hukum waris sebanyak 300 pasal, yang dimulai dari Pasal 830 sampai dengan Pasal 1130 KUH Perdata. Dalam KUH Perdata tidak ditemukan pengertian hukum waris, tetapi yang ada hanya konsep-konsep tentang pewarisan, orang yang berhak dan tidak berhak menerima warisan. Dengan meninggalnya seseorang tersebut maka seluruh harta kekayaannya beralih kepada ahli waris. Terjadinya pewarisan (warisan terbuka) dapat 
dilihat dari Pasal 830 BW yang menyatakan bahwa pewarisan hanya terjadi karena kematian. Jadi jelaslah bahwa kematian seseorang tersebut merupakan syarat utama dari terjadinya pewarisan dalam KUH Perdata. Hukum waris Adat adalah hukum Adat yang memuat garis-garis ketentuan tentang sistem dan asas-asas hukum waris, tentang harta warisan itu dialihkan penguasaan dan pemilikkannya dari pewaris kepada ahli waris (Hadikusuma, 2003:7). Hukum Adat lahir dan berkembang pada masyarakat adat dengan bentuk dan sifat hukum yang tak tertulis namun berlaku secara adat dan ditaati oleh warga masyarakat setempat.

Khisni dalam Hazairin mengklasifikasikan sistem waris dalam hukum Adat di Indonesia menjadi tiga yaitu: Pertama, sistem kewarisan individual, yang bercirikan harta peninggalan dapat dibagi-bagikan kepada para ahli waris seperti berlaku pada Masyarakat Bilateral (Jawa, Batak, Sulawesi, dan lainnya). Kedua, sistem kewarisan kolektif, yang bercirikan harta peninggalan itu diwarisi oleh sekumpulan ahli waris dan menjadi milik bersama. Harta waris tersebut hanya boleh digilir pemakaiannya (hanya mempunyai hak pakai saja) seperti berlaku pada Masyarakat Matrilineal (Minangkabau). Ketiga, sistem kewarisan mayorat, yang bercirikan harta peninggalan diwariskan keseluruhannya atau sebagian besar (sejumlah harta pokok dari suatu keluarga) kepada seorang anak saja. Praktek tersebut sebagaimana terdapat di Bali, yaitu hak mayorat diperuntukkan bagi anak laki-laki yang tertua dan di Tanah Samendo (Sumatera Selatan/Lampung), hak mayorat anak perempuan tertua (Khisni, 2017: 21-22).

\section{Sejarah hukum waris Islam}

Data sejarah tertulis yang menjelaskan tentang awal masuknya Islam di Nusantara adalah buku Riblab Ibnu Batthuthah yang judul aslinya buku ini adalah Tubfat al-Nu₹žhar Fi Gara'ib al-Amshar, karya Muhammad Ibn Batthuthah, seorang sejarawan Muslim asal daerah Thanja di Maroko yang pernah singgah di Samudera Pasai pada tahun 1345 M. Dikisahkan Ibnu Batthuthah sangat mengagumi Sulthan Malik al-Zhahir sebagai sosok raja yang murah hati, penganut fiqih mazhab Syafi'I, dekat dengan para ahli fiqih (fuqaha), gemar membaca dan berdiskusi, berakhlak tawadhu'. Beliau juga mengisahkan kebiasaan Malik al-Zhahir yang datang ke masjid untuk sholat jum'at dengan berjalan kaki (Bathuthah, t.t.: 619-620). Dari 
cerita Ibnu Battutah bisa disimpulkan bahwa Malik al-Zahir bukan hanya sebagai seorang raja namun juga seorang ahli hukum Islam.

Sebagaimana ditegaskan Muhammad Daud Ali dalam Amiur Nuruddin dan Azhari Akmal Tarigan bahwa sejak saat itu beberapa praktek keagamaan sudah dilaksanakan secara menyeluruh oleh masyarakat Islam Indonesia dalam lingkup abwal syakhsiyah (hukum keluarga) seperti perkawinan, perceraian, waris, lingkup peradilan, mu'amalah serta masalah ibadah. Bahkan Muhammad Daud Ali mengutarakan bahwa fiqh mawarits adalah sebagian dari hukum Islam yang telah berlaku secara yuridis formal atau menjadi hukum positif dalam tata hukum Nusantara yang isinya sebagian dari lingkup mu'amalah. Bagian hukum Islam ini menjadi hukum positif berdasarkan atau karena ditunjuk oleh peraturan undangundang (Nuruddin and Tarigan 2004:3).

Pada masa penjajahan Belanda, perkembangan hukum Islam di Indonesia diklasifikasikan dalam beberapa bentuk yaitu: pada masa VOC (Vereenigde Oost Indische Compagnie) atau Gabungan Perusahaan Dagang Belanda Hindia Timur yang semula bermaksud berdagang, namun keserakahan dan ketamakan mengubah tujuannya semula menjadi keinginan untuk menguasai kepulauan Indonesia sehingga VOC mempunyai dua fungsi yaitu pedagang dan pemerintahan. Karena badan-badan peradilan yang dibuat tidak berfungsi efektif akhirnya VOC memberikan ruang gerak yang lebih luas bagi masyarakat muslim untuk menggunakan fiqih mawarits dalam kasus-kasus sengketa selama kurang lebih dua abad.

Berbeda dengan masa penjajahan Jepang yang tidak mau mencampuri adat istiadat lokal dan praktek keagamaan dengan alasan mencegah resistensi, perlawanan dan oposisi yang tidak diinginkan. Jepang berusaha menghapus simbol-simbol pemerintahan Belanda di Indonesia yang membuat pengaruh kebijakan pemerintah Jepang terhadap hukum warisan tidak begitu signifikan. Pada masa Kemerdekaan, setelah diproklamirkannya Kemerdekaan RI, seluruh sistem hukum yang ada semuanya berdasarkan kepada sistem Hukum Nasional dan untuk menjaga agar tidak terjadi kekosongan hukum (kevakuman) maka semua susunan peradilan yang berlaku sebelum kemerdekaan dinyatakan masih tetap berlaku sebelum diadakan yang baru.

Beberapa tahun kemudian muncul Undang-Undang Peradilan Agama No 7 Tahun 1989 melalui Lembaran Negara Republik Indonesia Tahun 1989 No. 49 yang mempertegas 
Revitalisasi hukum waris Islam dalam penyelesaian kasus sengketa tanah ...(Lalu Supriadi Bin Mujib)

kedudukan dan kekuasaan Peradilan Agama. Dalam pasal 49 ditegaskan bahwa bahwa Pengadilan Agama bertugas dan berwenang memeriksa, memutus dan menyelesaikan perkara-perkara di tingkat pertama antara orang-orang yang beragama islam di bidang: a) perkawinan b) kewarisan, wasiat dan hibah yang dilakukan berdasarkan hukum islam. c) wakaf dan shadaqah.

Sebelum kemunculan Undang-Undang tersebut, pada tahun 1984, melalui SKB (Surat Keputusan Bersama) Ketua Mahkamah Agung dan Menteri Agama dibentuk panitia untuk merancang dan menyusun undang-undang yang kemudian dikenal dengan Kompilasi Hukum Islam (KHI) berkaitan dengan hukum perkawinan, kewarisan dan perwakafan yang selanjutnya dipergunakan oleh Pengadilan Agama dalam rangka melaksanakan tugas dan wewenangnya.

KHI merupakan rumusan fiqih yang kemudian ditetapkan menjadi pedoman dalam berperkara di pengadilan yang dalam prosesnya terbentuk melalui kajian terhadap kitabkitab fiqih lintas mazhab dengan mengumpulkan masukan dari para ulama dan pakar hukum Islam di Indonesia dan dengan mempertimbangkan kondisi sosio kultural masyarakat Indonesia. Kemudian melalui Instruksi Presiden No. 1 tahun 1991 yang diiringi dengan KMA No. 154 tahun 1991 meminta untuk menerapkan KHI di Pengadilan Agama di seluruh Indonesia. Dengan ini maka KHI menjadi pedoman hukum di semua lembaga Peradilan Agama di Indonesia yang berlaku untuk penduduk yang beragama Islam sampai saat ini.

Sejak tahun 1998 tepatnya pasca reformasi, sistem kenegaraan dan kepemerintahan mengalami dinamika yang signifikan. Keinginan agar KHI ini menjadi Undang-Undang mulai terbuka lebar apalagi sejak lahirnya UU No 3 tahun 2006 mengenai perubahan UU No 7 tahun 1989 tentang Peradilan Agama. Berdasarkan UU ini Peradilan Agama-lah yang berhak menyelesaikan perkara umat Islam seperti hukum penyelesaian perkawinan, perwakafan, hibah dan wasiat. Begitu pula penyelesaian persoalan shodakah, infak, zakat dan ekonomi syariah (Sarmadi 2013:11-12).

\section{Praktik pembagian harta waris}

Diskursus mengenai pembagian harta waris baik secara konsep maupun praktik menjadi sangat penting untuk didiskusikan bukan saja dilihat dari sudut pandang agama, namun 
Ijtihad: Jurnal Wacana Hukum Islam dan Kemanusiaan, Volume 19, No. 1, Juni 2019: 67-87

juga karena problematika sosial budaya, hukum dan ekonomi yang dihadapi oleh semua orang, tak terkecuali orang-orang yang berhak menerima warisan (ahli waris). Pada era penjajahan kolonial Belanda dan pasca kemerdekaan, ketika tanah pertanian tidak dianggap sebagai penghasilan produktif yang bisa menopang kehidupan masyarakat maka saat itu tidak muncul kasus dan permasalahan sebagaimana ditemukan pada masyarakat dewasa ini. Namun setelah ditemukan cara bercocok tanam yang baik dan berdampak pada meningkatnya hasil panen maka pada saat itu muncul ketamakan dan keserakahan untuk memiliki sesuatu yang bukan miliknya. Terjadi kesenjangan sosial antara masyarakat pada masa penjajahan Belanda yang jika dicermati merupakan bagian dari strategi penjajah Belanda untuk membuat langgeng daerah jajahannya. Penjajah Belanda menerapkan politik devide et empera (politik pecah belah) dalam aspek sosial dan politik yang muncul dalam bentuk mengkondisikan masyarakat Sasak terpecah menjadi dua klas sosial yaitu permenak (bangsawan) dan jajar karang (masyarakat biasa). Haji Lalu Munipi menuturkan: Kelas bangsawan menjadi "anak emas" kolonial dengan diberikannya peluang untuk bisa memiliki tanah yang sangat luas. Babkan dikatakan bahwa Mamik Rumilang seorang bangsawan asal Kotaraja di kecamatan Sikur Lombok. Timur memegang kepemilikan tanah seluas 600 hektar (6000 M2) yang merupakan pemberian dari Belanda (wawancara dengan Haji Lalu Munipi, 15 April 2015)..

Secara umum pembagian harta waris mengikuti hukum waris adat yang dalam prakteknya memberikan hak penuh kepada anak laki-laki untuk menerima dan mengatur harta warisan dari orang tuanya yang meninggal dunia. Anak perempuan akan menerima bagian jika sang anak laki-laki mau 'berbaik hati" membagi secara suka rela harta warisan yang diterimanya. Haji Lalu Lukman, B.A mengatakan "bukum waris Islam diterapkan di kalangan yang sangat terbatas yaitu pada keluarga tuan guru (tokoh agama) yang memiliki kesadaran yang tinggi dan memiliki motivasi yang kuat untuk mempraktek.kan ajaran agama Islam yang diterimanya ketika kembali ke tanah air" (wawancara dengan Haji Lalu Lukman, 20 April 2015). Senada dengan itu Haji Lalu Ridwan, B.A, mengatakan bahwa "cara pembagian harta warisan secara adat ini sudah dilakukan turun temurun dari nenek moyang masyarakat Sasak dan kita tidak berani melanggarnya" (wawancara dengan Haji Lalu Ridwan, 25 April 2015).

Pada kasus tertentu terkadang ditemukan bahwa anak perempuan dari orang yang meninggal dunia diberikan hak oleh saudaranya yang laki-laki untuk mengelola tanah 
Revitalisasi hukum waris Islam dalam penyelesaian kasus sengketa tanah ...(Lalu Supriadi Bin Mujib)

warisan secara bergiliran dengan saudara perempuannya yang lain. Lalu Khidir mengatakan "pada kasus tertentu karena faktor "belas kasihan" terkadang anak laki-laki memberikan hak. kepada saudaranya yang perempuan unuk mengelola tanab warisan secara bergiliran dengan saudaranya yang perempuan jïka mereka berjumlab lebih dari satu orang" (wawancara dengan Lalu Khidir, 15 April 2015).

Secara ringkas ditemukan bahwa masyarakat Sasak menganut tiga cara dalam pembagian warisan: Pertama, hibah yaitu pemberian harta waris dari pewaris kepada ahli waris sebelum pewaris meninggal dunia. Argumen yang dibangun adalah agar setelah pewaris meninggal dunia maka ahli waris (anak-anak, cucu dan ahli waris lainnya) tetap hidup rukun, damai dan penuh persaudaraan. Menurut hukum Adat, sebelum pewaris meninggal dunia sudah dapat terjadi perbuatan penerusan atau pengalihan harta kekayaan kepada ahli waris. Perbuatan penerusan atau pengalihan harta dari pewaris kepada ahli waris sebelum pewaris meninggal dunia dapat terjadi dengan cara penunjukkan, penyerahan kekuasaan atau penyerahan kepemikan atas bendanya oleh pewaris kepada ahli waris. Jika dilihat dari sudut pandang ini maka menurut hukum Adat, praktek pembagian harta warisan dengan cara hibah diperbolehkan. Berbeda dengan hukum Barat BW dan hukum Islam yang membolehkan harta warisan dibagi jika pewaris telah meninggal dunia.

Kedua, Musyawarah yaitu pembagian harta warisan dengan cara musyawarah dan mufakat dengan mempertimbangkan asas kemaslahatan antar para ahli waris. Argumen yang dibangun adalah kemashlahatan dan keutuhan sebuah keluarga dianggap lebih bijaksana. Sejalan dengan itu Kompilasi Hukum Islam menempatkan musyawarah dan mediasi sebagai sarana penting dalam penyelesaian kasus sengketa tanah. Dalam KHI pasal 193 disebutkan: "para abli waris dapat bersepakat melakukan perdamaian dalam pembagian harta warisan setelah masing-masing menyadari bagiannya".

Praktek ini tidak selalu berjalan mulus karena dalam pembagian harta waris misalnya bagian warisan yang semestinya diperoleh perempuan tidak diberikan secara langsung kepada ahli waris yang berhak menerimanya. Namun "dititipkan" pengelolaannya kepada saudaranya yang laki sampai batas waktu yang tidak jelas, bahkan terkadang sampai penerima waris meninggal dunia. Alasan yang dikemukakan untuk melegalkan praktek tersebut adalah "penitipan” harta waris kepada pihak laki-laki setelah pemberi waris meninggal dunia adalah 
Ijtihad: Jurnal Wacana Hukum Islam dan Kemanusiaan, Volume 19, No. 1, Juni 2019: 67-87

sebagai salah satu bentuk upaya untuk mendamaikan (shulhu) pihak ahli waris yang mungkin saja bersengketa (Komari n.d.:471).

Ketiga, Hukum Waris Islam (faraidh), yaitu pembagian harta warisan berdasarkan aturanaturan yang termuat dalam al-Qur'an dan hadits. Sistem pembagian ini diselesaikan melalui kesadaran diri dari para ahli waris dengan meminta pendapat dari para tokoh agama. Jika tidak ada kesadaran diri dan menimbulkan konflik antara ahli waris, maka jalan yang ditempuh melalui jalur Pengadilan Agama dan ditetapkan melalui KHI. Argumen yang dibangun untuk menggunakan sistem ini adalah bahwa ketentuan hukum waris sebagaimana tertuang dalam al-Qu'an dan hadits, lebih aman, dan menjanjikan balasannya di akhirat kelak.

\section{Faktor penyebab kasus sengketa tanah waris}

Beberapa faktor penyebab terjadinya kasus sengketa tanah warisan: Pertama, keserakahan dan ketamakan. Dalam konsep Islam, harta benda yang dimiliki seseorang adalah titipan Allah yang akan diminta pertanggung jawabannya kelak pada hari kiamat; bagaimana ia memperolehnya dan bagaimana ia membelanjakannya. Kepemilikan atas harta benda tersebut bukan bersifat individual dan mutlak sebagaimana paham individualistik yang dianut oleh masyarakat Barat, namun Islam memberi ruang sosial yang menuntut untuk dijalankan oleh seseorang. Tuntutan sosial ini ada yang bersifat tidak mengikat dan tidak wajib dilaksanakan seperti infak, sadaqah, hibah dan sebaliknya ada yang sifatnya mengikat secara hukum dan harus ditunaikan seperti kewajiban mengeluarkan zakat, warisan dan lain sebagainya. Dalam realitas sosial masyarakat terkadang ada orang-orang yang mengabaikan dan tidak memperhatikan aturan-aturan dan rambu -rambu yang sudah ditentukan bahkan melakukan pembangkangan terhadap nilai-nilai tersebut.

Masyarakat yang masih berpegang teguh terhadap local wisdom (nilai kearifan masyarakat setempat) dalam melakukan pembagian warisan harta benda pada dasarnya mengedepankan kehidupan bersama yang bersifat tolong-menolong guna mewujudkan kerukunan, keselarasan dan kedamaian di dalam hidup. Jika dicermati sejatinya nilai-nilai local wisdom yang dipraktekkan masyarakat Sasak sebagaimana disebutkan tidak bertentangan dengan ajaran Islam

Pada masyarakat seperti ini kepentingan hidup yang rukun dan damai lebih diutamakan dari sifat-sifat kebendaan dan mementingkan diri sendiri. Jika belakangan ini nampak 
Revitalisasi hukum waris Islam dalam penyelesaian kasus sengketa tanah ...(Lalu Supriadi Bin Mujib)

kecenderungan keluarga-keluarga yang mementingkan kebendaan dengan merusak kerukunan hidup kekerabatan atau ketetanggan, maka hal itu merupakan krisis akhlak. Salah satu bentuk krisis akhlak adalah munculnya sifat serakah dan tamak untuk memiliki harta benda yang bukan miliknya. Sebagaimana ditegaskan Riyadus Solihin: "sikap serakah manusia dan mau menang sendiri ketika musyawarah menjadi pemicu munculnya sengketa tanah waris" (wawancara dengan Riyadus Solihin, 15 April 2015). Senada dengan itu Haji Bahrudin mengatakan: "dengan munculnya sifat serakah maka mediasi yang dilakukan oleh pihak Desa tidak menemui jalan terang” (wawancara dengan Haji Bahruddin, 30 April 2015). Keserakahan dan ketamakan serta mau menang sendiri merupakan faktor penyebab munculnya kasus sengketa tanah waris. Beragam cara dilakukan untuk menunjukkan sifat ini seperti mengklaim secara sepihak bahwa tanah yang dimiliki adalah hibah dari pewaris (pemberi waris) atau bersikeras mengklaim ukuran yang bukan haknya.

Kedua, kurangnya sosialisasi mengenai hukum waris Islam. Realitas masyarakat menunjukkan bahwa sistem waris Islam sebagaimana termaktub dalam ayat-ayat al-Qur'an dan hadits yang lalu dijabarkan oleh para ulama dan fuqaha dalam kitab-kitab fiqih ternyata tidak tersosialisasikan secara baik dan merata. Indikator yang jelas mengenai hal tersebut muncul dalam bentuk saran dan masukan dari beberapa tokoh masyarakat, seperti yang disampaikan oleh Riyadus Solihin: "saran saya pibak Pengadilan Agama harus mensosialisasikan tentang fiqih mawaris yang termaktub dalam KHI dan tata cara pembagiannya supaya masyarat paham tentang pembagian tanab waris menurut bukum Islam (wawancara dengan Riyadus Solihin, 15 April 2015)”.

Ironisnya sekalipun masyarakat Sasak mayoritas -bahkan seluruhnya- memeluk agama Islam namun dalam kehidupan sehari-hari menggunakan hukum Adat untuk menyelesaikan pembagian harta waris. Hal ini terungkap dari pernyataan para tokoh adat dan budaya Sasak, Haji Lalu Ridwan, BA yang mengatakan: "cara pembagian warisan secara adat adalah temuan yang kami peroleh dari nenek moyang kami. Kami tidak berani melakukan pelanggaran apalagi tidak mengikuti nilai-nilai tersebut" (wawancara dengan Haji Lalu Ridwan, 25 April 2015).

Ketiga, ketidaktahuan masyarakat terhadap hukum waris Islam. Permasalahan sengketa tanah waris juga muncul karena faktor ketidaktahuan tentang hukum waris Islam, di mana ketika pewaris meninggal dunia muncul anggota ahli waris yang mengklaim bahwa 
harta benda tersebut sudah dihibahkan kepadanya. Akibatnya ahli waris yang juga berhak menerima, menjadi tidak memperoleh bagian yang semestinya. Dalam pengelolaan dan pemilikan tanah-tanah pertanian, masyarakat Sasak berpegang pada adat kebiasaan dan tradisi yang dilandasi oleh kejujuran, dan itu menjadi simbol dari nama tempat yang dihuni oleh masyarakat Sasak yaitu Lombok yang artinya lurus atau jujur (Arzaki dkk, 2001: 4).

Di satu sisi semua bentuk mu'amalah seperti jual beli, sewa menyewa, pembagian warisan, wakaf dan lain sebagainya yang berlaku pada masa lampau disampaikan oleh leluhur masyarakat Lombok secara lisan dari mulut ke mulut dengan disertai saksi namun kini banyak saksi-saksi tersebut yang sudah meninggal dunia. Sementara di sisi lain saat ini agar hak milik seseorang memiliki legalitas hukum maka semua bentuk transaksi harus tercatat secara resmi di badan hukum yang diakui oleh negara seperti Akta Notaris dan Pencatat Pembuat Akta Tanah (PPAT) sebagai bukti-bukti otentik administrtif atas klaim suatu perbuatan hukum..

Banyak kasus di pengadilan seputar harta warisan dapat dihindari jika pewaris dan ahli waris memiliki pengetahuan yang memadai tentang hukum waris. Opsi untuk mengatur pembagian warisan melalui wasiat atau berdasarkan hukum yang berlaku, seharusnya sudah menjadi pemikiran ketika pewaris masih hidup guna menghindari timbulnya masalah bagi para ahli waris setelah pewaris meninggal.

Bagi para ahli waris, pemahaman yang memadai tentang hukum waris juga sangat penting untuk menyadari hak dan kewajiban mereka sebagai ahli waris, dan opsi apa yang mereka miliki jika masalah ini sudah sampai pada tahap pengadilan. Banyak anggota masyarakat belum memahami tentang hukum waris Islam sehingga sering salah persepsi. Akibatnya terjadi konflik atau sengketa antara sesama ahli waris tersebut karena merasa pembagian tidak merata dan tidak sesuai dengan kaidah dan ajaran Islam.

\section{Revitalisasi hukum waris Islam}

Dalam kamus besar Bahasa Indonesia, revitalisasi berarti proses, cara, dan perbuatan menghidupkan atau menggiatkan kembali (https://kbbi.web.id/ revitalisasi). Dalam prakteknya hukum waris Islam tentu mengalami dinamika, maka pada konteks ini revitalisasi menjadi penting dilakukan. Revitalisasi dalam konteks hukum waris Islam maksudnya 
adalah menjadikan konsep dan praktek Islam dalam pembagian warisan menjadi lebih vital atau berdaya lagi (https://www.academia.edu/39017387). Revitalisasi muncul karena dua hal: Pertama, faktor internal. Faktor ini muncul disebabkan pemahaman keliru terhadap ajaran agama Islam dan itu telah membudaya, yang berakibat mematikan kreatifitas. Kedua, Faktor eksternal. Faktor ini muncul disebabkan adanya tekanan masyarakat luar dari suatu kelompok masyarakat yang ada, mengintervensi pola fikir masyarakat yang bersifat stagnan terhadap tatanan kehidupan yang awalnya tenang berubah menjadi kacau, berantakan yang menggiring mereka kepada situasi kemiskinan, kemelaratan, terhina, dan menjadi kelas rendah di negeri sendiri.

Dalam pemahaman teori hukum Islam klasik, dinyatakan bahwa hukum waris Islam merupakan ketetapan hukum yang harus diterapkan oleh setiap orang yang beragama Islam. Melaksanakannya dianggap melaksanakan perintah agama dan merupakan suatu bentuk ketaaan kepada Allah (Rahman, 1981: 34). Ia dianggap sebagai hukum yang berlaku secara mutlak. Khazanah pemikiran klasik ini direfleksikan sebagai dari rangkaian terhadap pemahaman terhadap teks-teks suci adalah qath'i baik dari segi wurud (sumber) maupun dilalah (petunjuk)-Nya (Sarmadi 2013:2). Dalam konteks ini maka hukum waris Islam menjadi solusi bagi segala permasalahan hukum yang terjadi pada masyarakat Sasak khususnya.

Di samping itu revitalisasi hukum waris Islam sebagai bentuk ketegasan terhadap pemberlakuan hukum. Dambaan akan munculnya suasana dan kondisi penerapan hukum Islam dengan mengacu kepada teks-teks al-Qur'an dan hadits muncul dari pernyataan dan komentar warga. Abdul Wahab mengatakan "kami merasa lebih aman dan selamat jika pembagian warisan mengacu kepada bukum waris Islam"(wawancara dengan Abdul Wahab, 30 April 2015). Senada dengan itu Haji Saparwadi Akbar mengatakan "kita harus kembali kepada hukum waris Islam” (wawancara dengan Haji Saparwadi Akbar, 30 April 2015). Senada dengan itu Agus Supiandi S.Pd berpendapat "hukum waris Islam adalah satu-satunya cara yang sah (legal) dalam pembagian hukum waris" (wawancara dengan Agus Supiandi, 30 April 2015). Dari sini maka realitas masyarakat menunjukkan bahwa keadilan hukum adalah sesuatu yang didambadambakan dalam sistem pembagian harta warisan. 
Ijtihad: Jurnal Wacana Hukum Islam dan Kemanusiaan, Volume 19, No. 1, Juni 2019: 67-87

\section{Penutup}

Hukum waris sebagai suatu sistem hukum dalam perkembangannya sangat dipengaruhi oleh dinamika sejarah yang panjang dan itu dimulai sejak era pra kolonial Belanda sampai saat sekarang ini. Setiap fase memiliki corak dan warna yang kemudian membentuk jati dirinya sebagai hukum waris Islam, hukum waris Adat dan hukum waris Barat. Ironisnya masyarakat Sasak yang secara mayoritas beragama Islam justru dalam praktek pembagian harta waris, sebagian besar menggunakan hukum waris Adat.

Demi menghindari terjadinya sengketa dan konflik akibat perbedaan dalam memahami keputusan tentang harta warits, maka sudah sepatutnya bagi pihak-pihak terkait baik unsur pemerintah maupun masyarakat sipil untuk mensosialisasikan secara massif hukum waris Islam kepada semua pihak. Menerapkan konsep hukum waris Islam dalam segala hal yang berkaitan dengan sengketa tanah waris sudah semestinya menjadi pilihan utama agar tercipta rasa aman, damai, tenang dalam menjalankan ajaran Islam juga sebagai bentuk dambaaan akan terciptanya keadilan hukum sekaligus keberpihakan terhadap ketegasan hukum.

\section{Daftar Pustaka}

Abbas, Syahrizal. 'Ahli Waris Pengganti Dalam Sistem Hukum di Indonesia'. dalam buku bunga rampai Problematika Hukum Kewarisan Islam Kontemporer di Indonesia, Jakarta: Puslitbang Kehidupan Keagamaan Balitbangdiklat Kemenag, 2012.

Ali, Muhammad Daud. Asas-Asas Hukum Islam; Pengantar Ilmu Hukum dan Tata Hukum Islam di Indonesia, Jakarta: Rajawali Press: 1991.

Arzaki, Djalaludin dan I Gde Madia. Nilai-Nilai Kearifan Budaya Lokal Suku Bangsa Sasak. dalam Pluralisme Kehidupan Bermasyarakat Relawan Untuk Demokrasi dan HAM. Mataram: CV Bina Mandiri, 2001.

Arikunto, Suharsimi. Prosedur Penelitian: Suatu Pendekatan Praktik. Cet. ke-1. Jakarta: Rineka Cipta, 1998.

Darmawan. Hukum Kewarisan Islam di Indonesia. Cet.I. Surabaya: UIN Sunan Ampel Press, 2014.

Fauzan, Shalih. al-Tahqiqat al-Mardhiyah Fi al-Mabahits al-Fardhiyah. Riyadh: Maktabah alMa'arif, $1419 \mathrm{H}$. 
Revitalisasi hukum waris Islam dalam penyelesaian kasus sengketa tanah ...(Lalu Supriadi Bin Mujib)

Fikri \&. Wahidin. 'Konsepsi Hukum Waris Islam dan Hukum Waris Adat: Analisis Kontekstualisasi dalam Masyarakat Bugis'. Al-Abkam: Jurnal Ilmu Syari'ah dan Hukum. Vol. 2, No. 2, 2017.

Hadikusuma, Hilman. Hukum Waris Adat, Bandung: Citra Aditya Bakti, 2003.

Haniru, Rahmat. 'Hukum Waris di Indonesia Perspektif Hukum Waris Islam dan Hukum Waris Adat'. Jurnal Hukama, Vol. 4, No. 2, Desember 2014.

Ibnu Batthuthah, Muhammad. Rihlah Ibnu Batthuthah, Beirut: Dar al-Kutub al-Ilmiyah. t.t. Ilyas. 'Kedudukan Ahli Waris Non Muslim Terhadap Harta Warisan Perwaris Islam Ditinjau Dari Hukum Islam Dan Kompilasi Hukum Islam'. Kanun Jurnal Ilmu Hukum. No. 65, Th. XVII, April, 2015.

Jamil, Rosidi. 'Hukum Waris dan Wasiat: Sebuah Perbandingan antara Pemikiran Hazairin dan Munawwir Sjadzali’. Al-Ahwal: Jurnal Hukum Keluarga Islam. Vol. 10, No. 1, 2017. Joko, Muhammad. Analisis Kontekstualisasi Hukum Waris Islam dan Hukum Adat dalam Masyarakat Ponorogo, (https://www.academia.edu/39017387 (disadur tanggal 27 Mei 2015).

al-Jurjani, Ali bin Muhammad. al-Ta'rifat. Cet. ke-3. Beirut: Dar al-Kitab al-Arabi, 1417 H. Karim, Muchith A. (eds). Problematika Hukum Kewarisan Islam Kontemporer di Indonesia. Jakarta:

Pusat Litbang Kehidupan Beragama (Indonesia), eds.Kementerian Agama RI, Badan Litbang dan Diklat, Puslitbang Kehidupan Keagamaan, 2012.

Kartodirjo, Sartono. Pendekatan Ilmu Sosial dalam Metodologi Ilmu Sejarah. Jakarta: Gramedia Pustaka Utama, 1999.

Khisni, H.A. Hukum Waris Islam. Cet. ke-6. Semarang: UNISSULA Press. 2017.

Komari. 'Dinamisasi Dan Elastitisas Hukum Kewarisan Islam'. Jurnal Hukum dan Peradilan. Vol. 1, No. 3, 2012.

Mu'alim, Amir, Yusdani. Konfigurasi Pemikiran Hukum Islam. Yogyakarta: UII Press, 2011.

Muhibbuddin, Muhammad. 'Pembaruan Hukum Waris Islam di Indonesia'. Abkam: Jurnal Hukum Islam. Vol. 3 No 2, 2015.

Mushthafa, Ibrahim (et). al-Mu'jam al-Wasith. Istanbul: Dar al-Da'wah, Juz.1, 1410 H.

Nasution, Adelina. 'Pluralisme Hukum Waris di Indonesia'. Vol. 5, No. 1, 2018. 
Ijtihad: Jurnal Wacana Hukum Islam dan Kemanusiaan, Volume 19, No. 1, Juni 2019: 67-87

Nawawi, Hadari. Metode Penelitian Bidang Sosial. Yogyakarta: Gadjah Mada University Press, 1993.

Nuruddin, Amiur and Azhari Akmal Tarigan. 2004. Hukum Perdata Islam Di Indonesia: Studi

Kritis Perkembangan Hukum Islam Dari Fikih, UU No. 1/1974, Sampai KHI. Ed. 1.

Rawamangun, Jakarta, Indonesia: Kencana.

Parman, Ali. Kewarisan Dalam Al-Qur'an: Suatu Kajian Pendekatan Hukum Dengan Pendekatan

Tafsir Tematik. Jakarta: Raja Grafindo Persada, 1995.

Rajagukguk, Erman. Pluralisme Hukum Waris: Studi Kasus Hak Wanita di Pulau Lombok Nusa

Tenggara Barat. t.t.

Rahman, Fathur. Ilmu Waris. Cet. 2. Bandung: Alma’rif, 1981.

Ramulyo, M. Idris. 'Suatu Perbandingan Antara Ajaran Syafi'i Hazairin dan Wasiat Wajb di Mesir, Tentang Pembagian Warisan Untuk Cucu Menurut Islam'. Majalah Hukum dan Pembangunan. No. 2 Tahun XII, Jakarta: Maret 1982.

Sakirman. 'Konvergensi Pembagian Harta Waris Dalam Hukum Islam. Jurnal Al-Adalah. Vol. 13, No 3, 2016.

Sarmadi, A. Sukris. Hukum Waris Islam di Indonesia: Perbandingan Kompilasi Hukum Islam dan Figh Sunni. Ngaglik, Sleman, Yogyakarta: Aswaja Pressindo, 2013.

Setiadi, Wahyu and Slamet Sumarto. 'Pembagian Harta Warisan pada Masyarakat Muslim Desa Sugihan Kecamatan Tengaran Kabupaten Semarang. Unnes Civic Education Jurnal. Vol. 3, No. 2, 2014.

Suharsimi Arikunto. Prosedur Penelitian: Suatu Pendekatan Praktik. Jakarta: Rineka Cipta, 1992. Susylawati, Eka. 'Penerapan Hukum Waris Islam dalam Perkara Waris di Pengadilan Agama Pamekasan’. AL-IHKAM: Jurnal Hukum \& Pranata Sosial. Vol. 9, No. 2, 2015.

Saebani, Bani Ahmad. Metode Penelitian. Cet. ke-1. Bandung: Pustaka Setia.), Cet. 1, 2008.

Sabiq, Sayyid. Fiqh al-Sunnah, Kairo: Dar al-Fath, Jilid. 3, 1422 H.

Syarifudin, Amir. Hukum Kewarisan Islam. Cet. 2. Jakarta: Prenada Media, 2005.

Van Der Kraan, Alfons. Lombok; Penaklukan, Penjajahan dan Keterbelakangan 1870-1940, terjemahan. Mataram: Lengge Printika, 2009.

Wahyuni, Afidah. 'Sistem Waris Dalam Perspektif Islam dan Peraturan Perundangundangan Di Indonesia'. SAL AM: Jurnal Sosial dan Budaya Syar-i, Vo. 5, No. 2, 2018. 
Revitalisasi hukum waris Islam dalam penyelesaian kasus sengketa tanah ...(Lalu Supriadi Bin Mujib)

Zedienz.wordpress.com/2015/10/30/revitalisasi-budaya-dan-tradisi-dalam-islam-danpendidikan-agama-islam. (Disadur tanggal 29 Mei 2015

https://kbbi.web.id/revitalisasi, disadur tanggal 25 Mei 2015

www.badilag.net/seputar-peradilan- agama/berita-daerah/kpta-mataram. Dikutip pada tanggal 5 April 2015.

www.badilag.net/seputar-peradilan- agama/berita-daerah/kpta-mataram. Dikutip pada tanggal 5 April 2015.

Wawancara dengan Haji Lalu Munipi (Tokoh Agama asal Kotaraja, Umur 75 Tahun), Tanggal 15 April 2015

Wawancara dengan Haji Lalu Lukman (Tokoh Masyarakat asal Padamara, Umur 78 Tahun), Tanggal 20 April 2015

Wawancara dengan Haji Lalu Ridwan, B.A (Tokoh Masyarakat asal Desa Kotaraja 70 Tahun), Tanggal 25 April 2015

Wawancara dengan Lalu Khidir (Tokoh Masyarakat asal Kotaraja, Umur 60 Tahun), Tanggal 15 April 2015

Wawancara dengan Riyadus Solihin, S.Pdi (Tokoh Masyarakat asal Tete Batu Selatan, Umur 25 tahun), Tanggal 15 April 2015

Wawancara dengan Haji Bahruddin (anggota masyarakat yang terlibat sengketa tanah asal

Kembang Kuning, Umur 67 Tahun), Tanggal 30 April 2015

Wawancara dengan Abdul Wahab (anggota masyarakat yang terlibat sengketa tanah asal

Lendang nangka, Umur 32 Tahun), Tanggal 30 April 2015

Wawancara dengan Haji Saparwadi Akbar (Tokoh masyarakat asal Tete Batu, Umur 30 Tahun), Tanggal 30 April 2015

Wawancara dengan Agus Supiandi, (Tokoh Masyarakat asal Lendang Nangka Utara, Umur

29 Tahun), Tanggal 30 April 2015 
